\title{
PENGARUH PROSES BELAJAR MENGAJAR (PBM) DAN KEDISIPLINAN DOSEN TERHADAP KEPUASAN MAHASISWA PROGRAM STUDI TEKNIK LISTRIK POLITEKNIK NEGERI MALANG
}

\author{
Sigit Setya Wiwaha ${ }^{1}$, Hari Sucipto ${ }^{2}$, Rokiyah $^{3}$ \\ 1,2,3 Jurusan Teknik Elektro, Politeknik Negeri Malang, Indonesia \\ 1 sigit.setya@polinema.ac.id
}

(Artikel diterima: Oktober 2019, direvisi: September 2019, diterima untuk terbit: Januari 2020)

\begin{abstract}
Abstrak - Perguruan Tinggi sebagai salah satu lembaga yang bergerak di bidang pendidikan diharapkan mampu menghasilkan lulusan yang mampu menjawab tantangan dan kebutuhan pasar. Untuk memenuhi tuntutan tersebut perguruan tinggi harus mampu meningkatkan kemampuannya dalam mendidik mahasiswa sehingga berhasil memenuhi harapan yang diinginkan stakeholder. Penelitian ini bertujuan untuk mengetahui apakah proses belajar mengajar (PBM) dan kediplinan dosen di program studi teknik listrik sudah bisa memenuhi harapan dan memberikan kepuasan terhadap mahasiswa. Manfaat hasil dari penelitian akan sejalan dengan tujuan penelitian, bilamana tujuan diatas dapat dicapai ,maka dapat ditindak-lanjuti secara institusional dalam peningkatan proses belajar mengajar (PBM) dan kedisiplinan dosen dalam melayani mahasiswa sehingga diharapkan pelayanan yang baik kepada mahasiswa dapat dicapai.
\end{abstract}

Kata kunci: PBM, Kedisiplinan, Kepuasan.

\section{Pendahuluan}

Perguruan Tinggi sebagai salah satu lembaga yang bergerak di bidang pendidikan diharapkan mampu menghasilkan lulusan yang mampu menjawab tantangan dan kebutuhan pasar. Untuk memenuhi tuntutan tersebut perguruan tinggi harus mampu meningkatkan kemampuannya dalam mendidik mahasiswa sehingga berhasil memenuhi harapan yang diinginkan stakeholder.

Salah satu upaya yang dilakukan adalah dengan memberikan pelayanan yang memuaskan bagi mahasiswa baik terkait dengan pelayanan akademik, proses belajar mengajar, sarana dan prasana maupun terkait dengan kualitas tenaga pengajar.

Tujuan dari penelitian ini adalah sebagai berikut: 1 . Menganalisa pengaruh Proses Belajar Mengajar (PBM) Terhadap Kepuasan Mahasiswa, 2. Menganalisa pengaruh Kedisiplinan Dosen Terhadap Kepuasan Mahasiswa, 3. Menganalisa pengaruh Proses Belajar Mengajar (PBM) dan Kedisiplinan Dosen Terhadap Kepuasan Mahasiswa.

\section{Tinjauan Pustaka}

\section{A. Pembelajaran}

Isjoni (2009: 11) mengemukakan bahwa, "Pembelajaran adalah sesuatu yang dilakukan oleh siswa, bukan dibuat untuk siswa". Pendapat tersebut mengungkapkan bahwa siswa adalah pelaku utama dalam sebuah pembelajaran, sehingga proses pembelajaran sebaiknya mengutamakan kebutuhan siswa akan ilmu pengetahuan dan aktivitassosial mereka agar kemampuan siswa dari segi kognitif, afektif, dan psikomotorik akan mengalami perkembangan.

Pembelajaran adalah proses interaksi peserta didik dengan pendidik atau sumber belajar pada suatu lingkungan belajar.Pembelajaran merupakan bantuan yang diberikan pendidik agar dapat terjadi proses perolehan ilmu dan pengetahuan, penguasaan kemahiran dan tabiat, serta pembentukan sikap dan kepercayaan kepada peserta didik.
Dengan kata lain, pembelajaran adalah proses untuk membantu peserta didik agar dapat belajar dengan baik.

lmu pengetahuan kepada peserta didik tetapi juga membimbing atau memfasilitasi siswa dalam menemukan pengetahuan dan pengalaman belajar. Pendidikan dan pengajaran dapat berhasil sesuai dengan harapan dipengaruhi faktor-faktor yang saling berkaitan dan saling menunjang.

\section{B. Metode Pembelajaran}

Bruce Joyce, Marsha Weil, dan Emily Calhoun (2009) berpendapat, model pembelajaran mempunyai makna yang lebih luas dari strategi dan prosedur. Pemilihan model pembelajaran harus disesuaikan dengan situasi kelas yang dihasilkan dari kerja sama antara guru dan siswa. Model pembelajaran disusun berdasarkan berbagai prinsip atau teori pengetahuan. Para ahli menyusun metode pembelajaran berdasarkan prinsip-prinsip pembelajaran, teori-teori psikologis, sosiologis, analisis sistem, atau teori-teori lain yang mendukung. Model pembalajaran adalah suatu rencana atau pola yang dapat digunakan untuk membentuk kurikulum

(rencana pembelajaran jangka panjang), merancang bahan- bahan pembelajaran, dan membimbing pembelajaran di kelas atau yang lain.

Metode pembelajaran dari kurikulum yang selama ini dipakai telah membuat mahasiswa cenderung pasif dan hanya mendengarkan dosen mengajar di kelas daripada mencari informasi atau pengetahuan lebih dari apa yang diajarkan di sekolah. Jarang sekali dosen yang memberi tugas untuk membaca buku sebanyak-banyaknya.

Sebaiknya tugas yang diberikan lebih berbentuk sebuah proyek yang menyenangkan, dimana mahasiswa dituntut untuk banyak membaca dari berbagai literatur. Dengan begitu wawasan mereka akan berkembang dan akan menciptakan iklim membaca. Membaca bukan dianggap sebagai hal yang membosankan dan tidak menarik, melainkan sebagai hal menyenangkan,mahasiswa juga diwajibkan untuk membaca sejumlah buku, merangkumnya sebagai syarat kelulusan dari suatu mata kuliah. 


\section{Mahasiswa}

Secara umum, mahasiswa adalah orang yang belajar di perguruan tinggi, baik di universitas, institut, politeknik maupun akademi. Mahasiswa adalah seseorang yang sedang dalam proses menimba ilmu ataupun belajar dan terdaftar sedang menjalani pendidikan pada salah satu bentuk erguruan tinggi yang terdiri dari akademik, politeknik, sekolah tinggi, institut dan universitas (Hartaji, 2012). Menurut Kamus Besar Bahasa Indonesia (KBBI), mahasiswa adalah mereka yang sedang belajar di perguruan tinggi. Mahasiswa dapat didefinisikan sebagai individu yang sedang menuntut ilmu ditingkat perguruan tinggi, baik negeri maupun swasta atau lembaga lain yang setingkat dengan perguruan tinggi.

Seorang mahasiswa dikategorikan pada tahap perkembangan yang usianya 18 sampai 25 tahun. Tahap ini dapat digolongkan pada masa remaja akhir sampai masa dewasa awal dan dilihat dari segi perkembangan, tugas perkembangan pada usia mahasiswa ini ialah pemantapan pendirian hidup (Yusuf, 2012).

Mahasiswa dapat didefinisikan sebagai individu yang sedang menuntut ilmu ditingkat perguruan tinggi, baik negeri maupun swasta atau lembaga lain yang setingkat dengan perguruan tinggi (Siswoyo, 2007).

Mahasiswa dinilai memiliki tingkat intelektualitas yang tinggi, kecerdasan dalam berpikir dan perencanaan dalam bertindak. Berpikir kritis dan bertindak dengan cepat dan tepat merupakan sifat yang cenderung melekat pada diri setiap mahasiswa, yang merupakan prinsip yang saling melengkapi.

Membicarakan pelayanan berarti membicarakan suatu proses kegiatan yang konotasinya lebih kepada hal yang abstrak (intangible). Pelayanan adalah merupakan suatu proses, proses tersebut menghasilkan suatu produk yang berupa pelayanan, yang kemudian diberikan kepada pelanggan.

Secara sederhana istilah layanan atau service bisa diartikan sebagai "Melakukan sesuatu bagi orang lain" (Tjiptono, 2012:3). Definisi pelayanan menurut Supranto (2006:227) "Pelayanan merupakan suatu kinerja penampilan, tidak berwujud dan cepat hilang lebih dapat dirasakan daripada dimiliki, serta pelanggan lebih dapat berpartisipasi aktif dalam proses mengkonsumsi jasa tersebut". "Secara umum, pelayanan pada dasarnya adalah kegiatan yang ditawarkan oleh organisasi atau perorangan kepada konsumen (consumer atau yang dilayani), yang bersifat tidak berwujud dan tidak dapat dimiliki" (Prastowo, 2012:241).

"Layanan konsumen meliputi berbagai aktivitas di seluruh area bisnis yang berusaha mengombinasikan mulai dari pemesanan, pemrosesan, hingga pemberian hasil jasa melalui komunikasi untuk mempererat kerja sama dengan konsumen" (Lupiyoadi dan Hamdani, 2009:139).

Menurut Moenir (2001:26) "Pelayanan umum adalah kegiatan yang dilakukan oleh seseorang atau sekelompok orang dengan landasan faktor materiel melalui sistem, prosedur dan metode tertentu dalam rangka usaha memenuhi kepetingan orang lain sesuai dengan haknya".

Berdasarkan definisi para ahli tersebut maka dapat disimpulkan bahwa pelayanan merupakan suatu kegiatan yang tidak berwujud berupa aktivitas antara pemberi jasa dan penerima jasa agar tercipta kerja sama diataranya.
Menurut Rangkuti (2006:30), "Kepuasan pelanggan didefinisikan sebagai respon pelanggan terhadap ketidaksesuaian antara tingkat kepentingan sebelumnya dan kinerja aktual yang dirasakan setelah pemakaian".

Oliver dalam Barnes (2003:64) mengemukakan definisi kepuasan pelanggan sebagai berikut : Kepuasan adalah tanggapan pelanggan atas terpenuhinya kebutuhannya. Hal ini berarti penilaian bahwa suatu bentuk keistimewaan dari suatu barang atau jasa ataupun barang/jasa itu sendiri memberikan tingkat kenyamanan yang terkait dengan pemenuhan suatu kebutuhan, termasuk pemenuhan kebutuhan di bawah harapan atau pemenuhan kebutuhan melebihi harapan pelanggan.

Tse dan Wilton dalam Tjiptono (2012:311) mengemukakan kepuasan merupakan, "Respon pelanggan terhadap evaluasi persepsi atas perbedaan antara harapan awal sebelum pembelian (atau standar kinerja lainnya) dan kinerja aktual produk sebagaimana dipersepsikan setelah memakai atau mengkonsumsi produk bersangkutan".

Pendapat lain oleh Fornell dalam Tjiptono (2012:311) kepuasan yaitu, "Evaluasi purnabeli keseluruhan yang membandingkan persepsi terhadap kinerja produk dengan ekspektasi pra-pembelian".

Menggunakan bahasa lebih sederhana Kotler dalam Lupiyoadi dan Hamdani (2009:192) menyatakan "Kepuasan merupakan tingkat perasaan dimana seseorang menyatakan hasil perbandingan atas kinerja produk (jasa) yang diterima dan yang diharapkan".

Beberapa pendapat para ahli di atas mengenai definisi kepuasan pelanggan dapat ditarik kesimpulan bahwa kepusan pelanggan merupakan perasaan kecewa atau senang yang merupakan respon pelanggan terhadap barang atau jasa yang dikonsumsinya, dimana pada saat sebelum menggunakan pelanggan memiliki harapan-harapan yang akan menimbulkan persepsi terhadap kinerja dari produk tersebut. Kepuasan akan tercapai apabila kinerja produk memenuhi atau setidaknya melampaui harapan-harapan pelanggan.

\subsection{Faktor Yang Mempengaruhi Kepuasan Pelanggan}

Kepuasan pelanggan merupakan tingkat perasaan seseorang dimana seorang pelanggan menyatakan hasil perbandingan antara kinerja (produk/jasa) yang diterima dengan yang diharapkan. Tingkat kepuasan masing-masing pelanggan berbeda-beda tergantung pada faktor yang mempengaruhi masingmasing pelanggan tersebut, kepuasan dapat dipengaruhi beberapa faktor.

Menurut Barnes (2003:82) faktor-faktor yang mempengaruhi tingkat kepuasan pelanggan terhadap penyedia jasa ataupun terhadap organisasi dapat dilihat dalam lima level pemicu kepuasan pelanggan terhadap pelayanan jasa, yaitu : 1. Produk atau jasa inti, ini adalah hal yang paling mendasar yang ditawarkan kepada pelanggan sekaligus hal yang tersulit bagi perusahaan untuk membuatnya lain dari pada yang lain, 2. Sistem dan layanan pendukung, ini meliputi layanan-layanan pendukung yang bisa meningkatkan kelengkapan dari layanan atau produk inti, seperti; sistem pembayaran dan penghantaran, kemudahan memperoleh produk, jam pelayanan, level karyawan, komunikasi informasi, sistem inventarisasi, pendukung teknis dan perbaikan, layanan bantuan via telepon, dan juga program-program lain yang mendukung produk inti, 
3. Performa teknis, berkaitan dengan apakah perusahaan menetapkan produk inti dan layanan pendukungnnya dengan benar (mengikuti standar yang ada, penghantaran tepat waktu, menepati janji, sedikit kesalahan pada produk dan jasa). Penekanannya adalah perusahan menampilkan produk kepada pelanggan sesuai dengan yang dijanjikan, 4.Elemenelemen interaksi dengan pelanggan, mengacu pada interaksi penyedia jasa dengan pelanggan melalui tatap muka langsung atau melalui kontak berbasis teknologi; tingkat pelayanan pribadi, perhatian, kecepatan pelayanan, kualitas umum dan bagaimana orang diperlakukan dan dilayani, 5. Elemen emosional dimensi afektif pelayanan, yaitu menumbuhkan perasaan positif dalam diri pelanggan. Pelanggan akan merasa puas dengan banyak interaksi diantara penyedia jasa dan dirinya dari pada diacuhkan oleh penyedia jasa.

\section{Metode Penelitian}

\section{A. Tempat dan Waktu Penelitian}

Penelitian dilakukan di Politeknik Negeri Malang program studi teknik listrik dengan obyek yang diteliti Mahasiswa di program studi teknik listrik. Waktu penelitian dilakukan dari bulan Februari sampai Oktober 2019.

\section{B. Tahapan Penelitian}

Dalam Penelitian ini, desain yang digunakan adalah desain Explanantif dengan analisa (Regresi Linear) untuk mengukur hubungan antara variabel riset atau untuk menganalisis bagaimana pengaruh suatu variabel terhadap variabel lainnya.

\section{Teknik pengumpulan data}

dalam penelitian ini menggunakan metode survei, dengan alat bantu kuesioner tertutup, di mana responden memilih salah satu jawaban yang telah disediakan, dengan alternatif jawaban terdiri dari interval bernilai $1-5$.Variabel yang Diteliti

\section{Teknik Pengumpulan dan Analisis Data}

\section{Uji Validas Data}

Untuk menguji hasil kuesioner digunakan Uji validitas. Suatu kuesioner dapat dikatakan valid jika pertanyaan dari kuesioner tersebut mampu mengungkapkan sesuatu yang akan diukur oleh kuesioner itu sendiri. Untuk menguji validitas digunakan bantuan software SPSS 22 menggunakan tingkat signifikansi $5 \%$. Suatu pernyataan dikatakan valid bila nilai sig r lebih kecil dari alpha.

\section{Uji Reabilitas}

Reabilitas merupakan ukuran suatu kestabilan dan konsistensi responden dalam menjawab hal yang berkaitan dengan pertanyaan yang merupakan indikator suatu variabel dan disusun dalam bentuk kuesioner dengan formula Cronbach alpha $(\alpha)$ dan dapat memberikan hasil yang relatif tidak berbeda bila dilakukan pengukuran kembali terhadap gejala yang sama pada saat yang berbeda. Perhitungannya dengan menggunakan aplikasi SPSS 22.

\section{Normalisasi}

Uji normalitas bertujuan agar data terdistribusi normal apakah dalam model regresi, variabel bebas dan variabel terikat kedua-duanya mempunyai distribusi normal atau tidak.

Suatu model regresi yang baik menurut Ghozali, Imam adalah: a. Jika data (titik) menyebar disekitar garis diagonal dan mengikuti arahgaris diagonal atau grafik histogramnya menunjukan pola distribusi normal, maka model regresi memenuhi asumsi normalitas.

b. Jika data menyebar jauh dari diagonal dan atau tidak mengikuti arah garis diagonal atau grafik histogramnya tidak menunjukan pola distribusi normal, maka model regresi tidak memenuhi asumsi normalitas.

\section{Multikolinieritas}

Uji Multikolinieritas diperlukan untuk mengetahui ada tidaknya variabel independen yang memiliki kemiripan dengan variabel independen lain dalam satu model. Multikolinieritas digunakan untuk menunjukkan adanya hubungan linear diantara variabel-variabel bebasnya dalam model regresi. Multikolinieritas dapat dideteksi dengan nilai Variance Inflation Faktor (VIF). Hasil uji melalui VIF pada hasil output SPSS 22 tabel Coefficients, masing masing variabel independent memiliki VIF tidak lebih dari 10 dan tolerance lebih besar dari 0.10 , Maka dapat dinyatakan model regresi terbebas Multikolinieritas dan dapat digunakan dalam penelitian.

\section{Pengujian Hipotesis}

Uji Hipotesis digunakan untuk menguji apakah koefisien regresi yang didapat signifikan. Koefisien tidak sama dengan nol menandakan bahwa ada pengaruh dari variabel bebas terhadap variabel terikat.

\section{Pembahasan}

\section{Hasil Uji Validas Data}

hasil pengolahan, semua butir pertanyaan mempunyai nilai $r$ hitung (Correlated Item Total Correlation) lebih besar dari pada nilai $r$ tabel $(0,361)$, maka dapat disimpulkan semua butir pertanyaan valid.

Tabel 4.1. Hasil Uji Validitas Variabel PBM(X1)

\begin{tabular}{|c|c|c|c|}
\hline $\begin{array}{c}\text { Butir } \\
\text { Pertanyaan }\end{array}$ & $\begin{array}{c}\text { r hitung } \\
\text { (CorrelatedItem Total } \\
\text { Correlation) }\end{array}$ & $\mathbf{r}$ tabel & Keterangan \\
\hline 1 & 0,573 & 0,361 & Valid \\
\hline 2 & 0,475 & 0,361 & Valid \\
\hline 3 & 0,667 & 0,361 & Valid \\
\hline 4 & 0,564 & 0,361 & Valid \\
\hline 5 & 0,492 & 0,361 & Valid \\
\hline 6 & 0,647 & 0,361 & Valid \\
\hline
\end{tabular}

Tabel 4.2. Hasil Uji Validitas Variabel Kedisiplinan Dosen (X2)

\begin{tabular}{|c|c|c|c|}
\hline $\begin{array}{c}\text { Butir } \\
\text { Pertanyaan }\end{array}$ & $\begin{array}{c}\text { r hitung } \\
\text { (CorrelatedItem Total } \\
\text { Correlation) }\end{array}$ & $\mathbf{r}$ tabel & Keterangan \\
\hline 1 & 0,693 & 0,361 & Valid \\
\hline 2 & 0,581 & 0,361 & Valid \\
\hline 3 & 0,534 & 0,361 & Valid \\
\hline 4 & 0,533 & 0,361 & Valid \\
\hline 5 & 0,657 & 0,361 & Valid \\
\hline
\end{tabular}


Tabel 4.3. Hasil Uji Validitas Variabel Kepuasan Mahasiswa (Y)

\begin{tabular}{|c|c|c|c|}
\hline $\begin{array}{c}\text { Butir } \\
\text { Pertanyaan }\end{array}$ & $\begin{array}{c}\text { r hitung (Correlated } \\
\text { Item Total Correlation) }\end{array}$ & r tabel & Keterangan \\
\hline 1 & 0,604 & 0,361 & Valid \\
\hline 2 & 0,624 & 0,361 & Valid \\
\hline 3 & 0,641 & 0,361 & Valid \\
\hline 4 & 0,663 & 0,361 & Valid \\
\hline 5 & 0,585 & 0,361 & Valid \\
\hline
\end{tabular}

\section{Hasil Uji Reabilitas}

Hasil uji reliabilitas tersebut menunjukkan bahwa semua variabel mempunyai koefisien Alpha yang cukup besar yaitu diatas 0,60 sehingga dapat dikatakan semua konsep pengukur masing-masing variabel dari kuesioner adalah reliabel sehingga untuk selanjutnya item-item pada masing-masing konsep variabel tersebut layak digunakan sebagai alat ukur.

Tabel 4.4. Hasil Uji Reabilitas

\begin{tabular}{|l|c|c|}
\hline \multicolumn{1}{|c|}{ Variabel } & Cronbach's Alpha & Keterangan \\
\hline PBM & 0.830 & Reliabel \\
\hline Kedisiplinan Dosen & 0.796 & Reliabel \\
\hline Kepuasan Mahasiswa & 0.808 & Reliabel \\
\hline
\end{tabular}

\section{Hasil Uji Normalitas}

Gambar 5.1 merupakan hasil uji normalitas data untuk semua dimensi secara simultan terhadap Kepuasan. Dapat dilihat titik-titik menyebar di sekitar garis diagonal dan penyebarannya mengikuti arah garis diagonal, yang berarti nilai residual berdistribusi normal, sehingga model regresi layak dipakai untuk memprediksi Kepuasan berdasarkan masukan semua variabel bebas.

\section{Gambar 4.1. Hasil Uji Normalitas}

Normal P.P Plot of Regression Standardized Residual

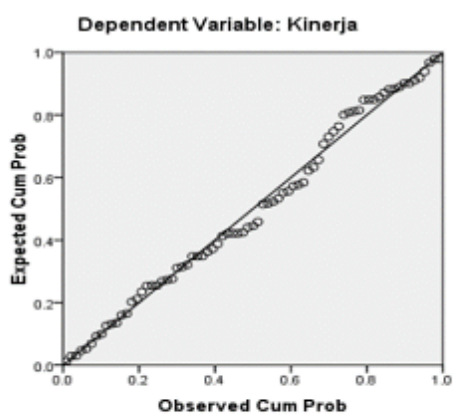

\section{Hasil Uji Multikolinieritas}

Dilihat dari nilai VIF yang diperoleh ketiga variabel ada disekitar angka 1 - 10, maka dapat dipastikan model yang digunakan dalam penelitian ini tidak terjadi multikolinieritas.

Tabel 4.5. Hasil Uji Multikolinieritas

\begin{tabular}{|cc|c|c|}
\hline \multicolumn{2}{|c|}{ Mode } & \multicolumn{2}{c|}{ Collinearity Statistic } \\
\hline I & (Costanta) & Tolerance & VIF \\
\hline & X1 & 0.990 & 1.010 \\
\hline & X2 & 0.922 & 1.085 \\
\hline
\end{tabular}

\section{Pengaruh Faktor PBM Terhadap Kepuasan Mahasiswa}

1. Persamaan garis regresi

Berdasarkan garis analisis, maka persamaan garis regresi dapat dinyatakan sebagai berikut :

$\mathrm{Y}=1,134 \mathrm{X} 1+2,200$

Persamaan tersebut menunjukkan bahwa nilai koefisien regresi bernilai positif sebesar 1,134 yang berarti jika Faktor PBM (X1) meningkat 1 poin maka Kepuasan Mahasiswa (Y) meningkat sebesar 1,134.

2. Koefisien korelasi ( $\mathrm{r}$ ) antara prediktor X1 dengan kriteriumY

Berdasarkan perhitungan denggan menggunakan SPSS didapatkan (rxiy) sebesar 0,761, karena koefisien korelasi (rxiy) tersebut bernilai positif maka dapat diketahui bahwa terdapat hubungan yang positif antara Faktor PBM dengan Kepuasan Mahasiswa.

3. Koefisien determinasi $\left(\mathrm{R}^{2}\right)$ antara prediktor $\mathrm{X} 1$ denganY.

Besarnya koefisien determinasi adalah kuadrat dari koefisien korelasi ( $\mathrm{R}^{2}$ ). Koefisien ini disebut koefisien penentu, karena varians yang terjadi pada variabel dependen dapat dijelaskan melalui varians yang terjadi pada variabel independen. Berdasarkan hasil analisis denggan menggunakan SPSS harga koefisien determinasi $\mathrm{X} 1$ terhadap $\mathrm{Y}\left(\mathrm{R}^{2} \mathrm{x}_{1} \mathrm{y}\right)$ sebesar 0,580 .

Hal ini menunjukkan bahwa variable Faktor PBM memiliki kontribuasi pengaruh terhadap Kepuasan Mahasiswa sebesar $58 \%$ sedangkan $42 \%$ ditentukan oleh variabel lain yang diteliti.

\section{Pengaruh Faktor Kedisiplinan Dosen Terhadap Kepuasan Mahasiswa}

1. Persamaan garis regresi

Berdasarkan garis analisis, maka persamaan garis regresi dapat dinyatakan sebagai berikut:

$\mathrm{Y}=0,184 \mathrm{X} 2+65,453$

Persamaan tersebut menunjukkan bahwa nilai koefisien regresi sebesar 0,184 .

2. Koefisien korelasi ( $\mathrm{r}$ ) antara prediktor $\mathrm{X} 2$ dengan $\mathrm{Y}$ Berdasarkan perhitungan denggan menggunakan SPSS $\left(\mathrm{rx}_{2} \mathrm{y}\right)$ sebesar 0,69 .

3. Koefisien determinasi $\left(\mathrm{R}^{2}\right)$ antara prediktor $\mathrm{X} 2$ denganY

Besarnya koefisien determinasi adalah kuadrat dari koefisien korelasi ( $\mathrm{R}^{2}$ ). Koefisien ini disebut koefisien penentu, karena varians yang terjadi pada variabel dependen dapat dijelaskan melalui varians yang terjadi pada variabel independen. Berdasarkan hasil analisis denggan menggunakan SPSS, harga koefisien determinasi X2 terhadap $\mathrm{Y}\left(\mathrm{R}^{2} \mathrm{x}_{2} \mathrm{y}\right)$ sebesar 0,005 .

\section{Pengaruh PBM dan Kedisiplinan Dosen Terhadap Kepuasan Mahasiswa}

1. Persamaan Garis Regresi Ganda.

Berdasarkan hasil analisis, maka persamaan regresi dapat dinyatakan dalam persamaan sebagai berikut: 
$\mathrm{Y}=1,186 \mathrm{X} 1+0,366 \mathrm{X} 2+13,123$

Persamaan tersebut menunjukkan bahwa nilai koefisien regresi X1 sebesar 1,186 yang berarti nilai Faktor PBM (X1) meningkat satu satuan maka Kepuasan Mahasiswa (Y) akan meningkat 1,186 satuan dengan asumsi X2 tetap, demikian juga nilai koefisien regresi X2 sebesar 0,366 yang berarti jika nilai Faktor Kedisipinan Dosen (X2) meningkat satu satuan maka nilai IPK (Y) akan meningkat 0,366 satuan dengan asumsi $\mathrm{X} 1$ tetap.

2. Koefisien korelasi (r) antara prediktor $\mathrm{X} 1$ dan $\mathrm{X} 2$ terhadap Y.

Berdasarkan hasil analisis denggan menggunakan SPSS menunjukkan bahwa koefisien korelasi X1 dan X2 terhadap Y (r y $(1,2))$ sebesar 0,773, karena Ry12 $(0,773)$ bernilai positif maka dapat diketahui bahwa Faktor PBM dan Faktor Kedisiplinan Dosen secara bersama-sama memiliki hubungan yang positif dengan Kepuasan Mahasiswa. Dengan demikian dapat dikatakan bahwa jika terdapat peningkatan Faktor PBM dan Faktor Kedisiplinan Dosen secara bersama-sama maka Kepuasan Mahasiswa juga akan meningkat.

3. Koefisien determinasi $\left(\mathrm{R}^{2}\right)$ antara prediktor $\mathrm{X} 1$ dan $\mathrm{X} 2$ terhadap Y.

Besarnya koefisien determinasi adalah kuadrat dari koefisien determinasi $\left(\mathrm{R}^{2}\right)$. Koefisien ini disebut koefisien penentu, karena varian yang terjadi pada variabel dependen dapat dijelaskan melalui varians yang terjadi pada variabel independen. Berdasarkan analisis denggan menggunakan SPSS, harga koefisien determinasi X1 dan X2 terhadap $\mathrm{Y}$ $\left(\mathrm{R}^{2} \mathrm{y}_{12}\right)$ sebesar 0,597. Hal ini menunjukkan bahwa 59,7\% perubahan pada variabel IPK (Y) dipengaruhi oleh Faktor PBM (X1), dan Faktor Kedisiplinan Dosen (X2), sedangkan $40,3 \%$ dipengaruhi oleh variabel lain yang tidak diteliti dalam penelitian ini

\section{Hasil Penelitian}

1. Pengaruh Faktor PBM terhadap Kepuasan Mahasiswa Hasil perhitungan menggunakan analisis regresi sederhana diketahui bahwa nilai koefisien korelasi (rxly) adalah 0,761. Hasil tersebut menunjukkan bahwa koefisien korelasi bernilai positif maka terdapat pengaruh positif variabel Faktor PBM terhadap Kepuasan Mahasiswa. Sedangkan p (sign) sebesar 0,000, koefisien determinasi (R2xly) sebesar 0,580 atau $58 \%$ yang artinya bahwa Faktor PBM mampu menjelaskan $58 \%$ perubahan IPK.

Berdasarkan hasil uji t diperoleh nilai thitung sebesar 9,321 . Hasil tersebut jika dibandingkan dengan ttabel sebesar 1,669 pada taraf signifikansi 5\% maka nilai thitung $>$ ttabel $(9.321>1,669)$. Sehingga dapat disimpulkan bahwa terdapat pengaruh positif dan signifikan Faktor PBM terhadap Kepuasan Mahasiswa.

2. Pengaruh Kedisiplinan Dosen terhadap Kepuasan Mahasiswa.

Hasil perhitungan menggunakan analisis regresi sederhana diketahui bahwa nilai koefisien korelasi (rx2y) adalah 0,069, sedangkan p (sign) sebesar 0,587, koefisien determinasi (R2x2y) sebesar 0,005 atau 0,5\%. Berdasarkan hasil uji t diperoleh nilai thitung sebesar 0,545 . Hasil tersebut jika dibandingkan dengan ttabel sebesar 0,678 pada taraf signifikansi $5 \%$ maka nilai thitung $<$ ttabel $(0,545<1,669)$. Sehingga dapat disimpulkan bahwa tidak terdapat pengaruh signifikan Faktor Kedisiplinan Dosen terhadap Kepuasan Mahasiswa.

3. Pengaruh PBM dan Kedisiplinan Dosen Tehadap Kepuasan Mahasiswa.

secara bersama-sama pengaruhnya terhadap Kepuasan Mahasiswa berdasarkan hasil perhitungan regresi ganda menunjukkan bahwa terdapat pengaruh positif dan signifikan Faktor PBM dan Faktor Kedisiplinan Dosen terhadap Kepuasan Mahasiswa. Hasil analisis diperolah harga koefisien korelasi (ry $(1,2))$ sebesar 0,773 , koefisien korelasi tersebut bernilai positif maka terdapat pengaruh positif variabel Faktor PBM dan Faktor Kedisiplinan Dosen terhadap Kepuasan Mahasiswa. Harga koefisien determinasi (R2y $(1,2))$ sebesar 0,597 atau 59\% yang berarti bahwa Faktor PBM dan Kedisiplinan Dosen mampu menjelaskan 59\% perubahan Kepuasan Mahasiswa. Sedangkan p (sign) sebesar 0,000 , hasil uji $\mathrm{F}$ diperoleh nilai $\mathrm{F}$ sebesar 45.928 . Hasil tersebut jika dibandingkan dengan Ftabel sebesar 3,99 pada taraf signifikansi 5\% maka nilai Fhitung > Ftabel $(45.928$ $>3,99$ ).

\section{Kesimpulan}

Berdasarkan hasil penelitian yang telah dilakukan maka dapat diambil kesimpulan sebagai berikut.

1. Terdapat pengaruh positif dan signifikan faktor PBM terhadap Kepuasan Mahasiswa program studi teknik listrik yang ditunjukkan dengan koefisien determinasi (R2x1y) sebesar 0,580 atau $58 \%$ yang artinya bahwa faktor PBM mampu menjelaskan $58 \%$ perubahan Kepuasan Mahasiswa dan Harga $F$ sebesar 86,885 dengan $\mathrm{p}($ sign $)=0,000<0,05$.

2. Faktor Kedisiplinan Dosen tidak berpengaruh terhadap Kepuasan Mahasiswa program studi teknik listrik yang ditunjukkan koefisien determinasi (R2x2y) sebesar 0,005 atau $0,5 \%$. Harga $F$ sebesar 0,298 dengan $p$ (sign) $=0,587>0,05$.

3. Terdapat pengaruh positif dan signifikan faktor PBM dan faktor Kedisiplinan Dosen secara bersama-sama terhadap Kepuasan Mahasiswa program studi teknik listrik, yang ditunjukkan dengan Harga koefisien determinasi $(\mathrm{R} 2 \mathrm{y}(1,2))$ sebesar 0,597 atau 59\% yang berarti bahwa faktor PBM dan faktor Kedisiplinan Dosen mampu menjelaskan 59\% perubahan Kepuasan Mahasiswa. Harga $\mathrm{F}$ sebesar 45,928 denganp (sign) $=$ $0,000<0,05$.

Adapun saran yang dapat diberikan antara lain:

Berdasarkan hasil penelitian, maka dapat di berikan saran kepada beberapa pihak yang terlibat dalam proses pembelajaran, diantaranya :

1. Bagi Mahasiswa

Sebaiknya mahasiswa selalu mengembangkan diri dan terus belajar meningkatkan kemampuanya dengan jalan belajar bersama dengan mahasiswa lainnya di luar 
jadwal PBM sehingga bisa menambah wawasan dan mengejar ketinggalan serta belajar lebih disiplin mengikuti ketentuan yang telah ditetapkan program studi maupun dosen bidang studi.

2. Bagi Pengajar

Pengajar hendaknya lebih kreatif dalam menyampaikan pengajaran kepada mahasiswa, supaya mahasisiswa semakin berminat untuk mengikuti mata kuliah dan termotivasi untuk meningkatkan kemampuan belajarnya. Pengajar hendaknya tidak hanya menerapkan disiplin yang tinggi tetapi juga memperhatikan kesulitan yang dialami mahasiswa sehingga pengajar perlu memberikan pendekatan yang berbeda dalam pelaksanaan perkuliahan walaupun tetap mengajarkan kedisiplinan tetapi juga memberikan ruang fleksibilitas kepada mahasiswa.

\section{Daftar Pustaka}

[1] Arikunto, Suharsimi. (2006). Prosedur Penelitian Suatu Pendekatan Praktik. Jakarta : PT. Rineka Cipta

[2] Bangun, Gladys Ema Sarlina. (2011). Perbedaan Self Directed Learning Siswa Sekolah Menengah Atas dan Sekolah Menengah Kejuruan di Yayasan Dharma Bakti Medan. Skripsi (diterbitkan). Psikologi, Universitas Sumatera Utara.

[3] Candiasa, I Made. (2010). Statistik Univariat dan Bivariat Disertai Aplikasi SPSS. Singaraja : Unit Penerbitan Universitas Pendidikan Ganesha.

[4] Asri Niti, Made Windu \& Dessy Seri Wahyuni (2013). Hubungan Antara Latar Belakang Pendidikan Mahasiswa dan Persepsi Mahasiswa tentang Profesionalisme Dosen Terhadap Prestasi Akademik Mahasiswa Pendidikan Teknik Informatika (Studi Kasus :Jurusan Pendidikan Teknik Informatika, Undiksha Singaraja).

[5] Widya Lestari, Ety Aprianti (2012). Faktor-Faktor Yang Mempengaruhi Hasil Belajar Mahasiswa Tingkat II Prodi D3 Kebidanan STIKES Mercubaktijaya Padang Tahun Ajaran 2011/2012. 